\title{
ANALISIS PENYERAPAN PANAS PADA COVER ACCU DI MOBIL SUV
}

\author{
Mohamad Faizal. ${ }^{1}$, Mariza Fitri ${ }^{2}$ \\ Program Studi Teknik Mesin, Institut Sains dan Teknologi Nasional, Jakarta Selatan, Indonesia ${ }^{12}$ \\ email :mfaizalh44@yahoo.com
}

\begin{abstract}
Batteries or accumulators on the car serves to store electrical energy in the form of chemical energy, which will be used to supply the system to the electric starter, ignition system, lights and other electrical components. In the car, the battery damage can occur due to many factors including temperature. Batteries that work at higher temperatures will have a life span that is lower than at normal room temperature $\left(25^{\circ} \mathrm{C}\right)$. Generally, the location of the battery is in the engine room so that the battery position was close to the engine. The car engine works at the optimum temperature $80^{\circ} \mathrm{C}-90^{\circ} \mathrm{C}$ so that the heat is around the engine room can be exposed directly to the battery and can affect the performance and lifetime of the battery. Adding insulation on cover, with low thermal conductivity coefficient will decrease heat transfer rate. Polyurethane as insulation with $7,5 \mathrm{~mm}$ thickness will maintenance battery liquid temperature $45,5{ }^{\circ} \mathrm{C}$ after running through three hundred minutes.
\end{abstract}

Keywords: Batteries, temperature, insulation, thermal conductivity, polyurethane.

\section{PENDAHULUAN}

Baterai / accu adalah alat yang dapat menyimpan energi listrik dalam bentuk energi kimia. Baterai berfungsi untuk menyuplai kebutuhan listrik terutama pada sistem starter saat mobil mulai dinyalakan. Kerusakan pada baterai dapat terjadi karena banyak faktor, salah satunya temperatur ekstrim. Temperatur tinggi saat baterai beroperasi dapat menurunkan siklus baterai, sehingga masa hidup baterai pada suhu lebih tinggi dari suhu normal $\left(25^{\circ} \mathrm{C}\right)$ akan lebih kecil.

Pada pengetesan awal yang dilakukan dengan kondisi mesin menyala dan idle selama 180 menit, didapatkan temperatur cairan baterai mencapai $64,4{ }^{\circ} \mathrm{C}$. Hal ini terjadi karena posisi baterai dan mesin di dalam kap mesin sangat dekat, sehingga panas dari mesin mobil terpapar langsung ke baterai. Meskipun baterai sudah dilengkapi dengan cover dari bahan plastik, namun cover dengan ketebalan 2,5 mm ini terlalu tipis dan tidak secara penuh menutupi baterai, sehingga cover ini tidak bagus dalam menyerap panas mesin, yang mana mesin bekerja pada suhu optimal $80-90{ }^{\circ} \mathrm{C}$.

Oleh karena itu, cover baterai perlu dianalisis penyerapan panasnya secara konduksi dan konveksi, sehingga cover dapat dimodifikasi dan ditambahkan isolasi agar dapat menyerap panas dengan baik dan temperatur cairan baterai saat beroperasi tidak ekstrim. Dengan suhu kerja yang tidak ekstrim, diharapkan baterai lebih tahan lama dengan siklus hidup yang tinggi.

\section{TINJAUAN PUSTAKA \\ Tinjauan Umum Baterai}

Baterai akumulator atau lebih dikenal dengan sebutan aki, adalah alat yang dapat menyimpan energi listrik dalam bentuk energi kimia. Di dalam standar internasional setiap satu sel akumulator memiliki tegangan sebesar 2 volt sehingga aki 12 volt memiliki 6 sel sedangkan aki 24 volt memiliki 12 sel. Aki merupakan sel yang banyak kita jumpai karena banyak digunakan pada sepeda motor maupun mobil. Aki termasuk sel sekunder karena selain dapat menghasilkan arus listrik, aki juga dapat diisi arus listrik kembali. Secara sederhana aki merupakan sel yang terdiri dari elektroda $\mathrm{Pb}$ sebagai anode dan $\mathrm{PbO}_{2}$ sebagai katode dengan elektrolit $\mathrm{H}_{2} \mathrm{SO}_{4}$.

Proses kimia yang terjadi secara simultan, reaksi secara kimia dinyatakan sebagai berikut :

Anoda : $\mathrm{Pb}+\mathrm{SO}_{4}{ }^{2-} \rightarrow \mathrm{PbSO}_{4}+2 \mathrm{e}^{-}$

Katoda : $\mathrm{PbO}_{2}+\mathrm{SO}_{4}{ }^{2-}+4 \mathrm{H}^{+}+2 \mathrm{e}^{-} \rightarrow \mathrm{PbSO}_{4}$ $+2 \mathrm{H}_{2} \mathrm{O}$

Reaksi total : $\mathrm{Pb}+\mathrm{PbO}_{2}+4 \mathrm{H}^{+}+2 \mathrm{SO}_{4}{ }^{2-}$ $\rightarrow 2 \mathrm{PbSO}_{4}+2 \mathrm{H}_{2} \mathrm{O}$

Baterai pada mobil berfungsi untuk menyimpan energi listrik dalam bentuk energi kimia, yang akan digunakan untuk menyuplai listik ke sistem starter, sistem pengapian, lampu- 
lampu dan komponen komponen kelistrikan lainnya.

Ketika mesin dalam keadaan mati, maka baterai berfungsi sebagai sumber energi untuk pengopersian lampu dan aksesoris mobil. Ketika mesin di starter pada awal akan mengendarai, baterai berfungsi sebagai sumber energi untuk sistem cracking untuk starter mobil. Ketika mesin dalam keadaan running atau berjalan, baterai dapat berfungsi sebagai sumber energi untuk kebutuhan listrik lainnya

\section{Penyebab Kerusakan Baterai}

Kebanyakan baterai dapat bertahan hidup sampai lima tahun pada penggunaan suhu normal, namun biasanya garansi baterai untuk mobil penumpang hanya sampai dua tahun. Berikut beberapa penyebab kerusakan baterai;

1. Level Elektrolit

Permukaan elektrolit baterai harus dipertahankan antara batas atas dan bawah, oleh karena itu harus diperiksa secara rutin. Kekurangan elektrolit akan menyebabkan material aktif terkespos dan baterai tidak dapat diisi. Kurangnya elektrolit baterai dapat terjadi karena adanya kebocoran pada kotak baterai, jarangnya melakukan perawatan, dan charging yang berlebihan sehingga menyebabkan gas yang berlebihan. Namun demikian, kelebihan elektrolit juga tidak berdampak baik. Kelebihan elektrolit akan menyebabkan korosi pada terminal baterai akibat tumpahnya cairan elektrolit pada terminal saat mobil sedang berjalan. Korosi tersebut akan menghambat kelancaran reaksi kimia pada baterai.

2. Korosi

Korosi terjadi pada terminal, connector, dan metal disekitar baterai, akibat cairan elektrolit yang tumpah, atau dari hasil kondensasi gas setelah charging. Korosi dapat menaikkan resistansi listrik, yang mana dapat menurunkan tegangan dan proses charging menjadi tidak efektif.

\section{Vibrasi}

Vibrasi yang berlebihan dapat menyebabkan longgarnya connector, pecahnya kotak, dan membahayakan komponen bagian dalam baterai.

4. Overcharging

Proses pengisian baterai dari sistem pengisian di dalam kendaraan atau menggunakan peralatan terpisah, yang dilakukan secara berlebihan akan mengakibatkan gassing. Terlalu banyak gassing yang terjadi maka banyak juga material aktif yang hilang dari pelat. Sehingga proses pengisian dapat terganggu.

5. Peralatan elektronik yang berlebihan
Pemakain piranti eletronik berlebihan pada mobil dapat mengurangi masa hidup baterai, terlebih jika perangkat kelistrikan tersebut digunakan pada saat kondisi mesin mati. Hal ini dapat menyebabkan baterai menjadi kosong, namun tidak ada input pengisian dari alternator.

6. Temperatur

Temperatur ambient merupakan faktor besar dalam masa hidup semua sistem baterai. Masa hidup baterai dapat berkurang setengahnya jika digunakan pada temperatur ekstrim. Kenaikan temperatur dapat menyebabkan kerusakan pada komponen baterai seperti korosi pada pelat positif dan siklus hidup baterai menjadi lebih singkat.

Temperatur juga mempengaruhi tingkat self discharge baterai, yaitu sebuah fenomena dimana sel-sel baterai kehilangan kemampuan untuk menyimpan energi listrik. Semakin rendah tingkat self discharge, semakin lama masa hidup baterai, dan self discharge baterai akan meningkat dengan peningkatan temperatur.

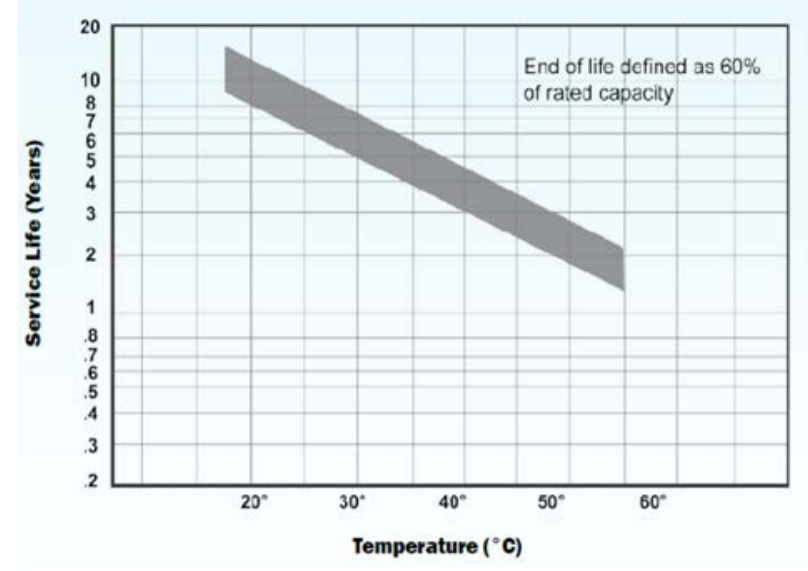

Gambar 1. Grafik Umur Baterai Berdasarkan Temperatur

Sumber : Battery Manufacturer

Endurance test merupakan pengujian yang dilakukan untuk mengetahui siklus hidup baterai. Pada test ini, diketahui bahwa siklus hidup baterai akan berkurang pada suhu yang lebih tinggi. Pada dasarnya, endurance test mengacu pada JIS D5301 dan pengujian siklus baterai dilakukan pada suhu $41 \pm 3^{\mathrm{O}} \mathrm{C}$.

Pada pengujian ini, baterai ditempatkan di dalam bak berisi air dengan suhu $41 \pm 3{ }^{\mathrm{O}} \mathrm{C}$, dengan level air berada $15 \mathrm{~mm}-25 \mathrm{~mm}$ di bawah permukaan atas baterai, dengan jarak $25 \mathrm{~mm}$ antara permukaan depan, samping, dan belakang baterai dengan dinding bak. Kemudian baterai dikosongan dan diisi sampai tegangan turun menjadi 7.2V. Pada standarnya, baterai dengan tegangan $7.2 \mathrm{~V}$ atau di bawahnya tidak dapat digunakan kembali. Untuk itu dari pengetesan ini, 
akan dicatat siklus pengisian dan pengosongan baterai sampai baterai mencapai akhir masa hidupnya..

Pada pengujian baterai untuk mobil PT. X, didapatkan hasil endurance test pada suhu $40^{\circ} \mathrm{C}$ adalah sebanyak 2600 siklus, sedangkan pada suhu $75^{\circ} \mathrm{C}$ adalah 1450 siklus. Pada temperatur $40^{\circ} \mathrm{C}$ adalah temperatur yang disarankan oleh manufaktur baterai PT. XY.

Tabel 1. Hasil Endurance Test.

\begin{tabular}{|c|c|c|c|c|}
\hline No & Battery Type & Temperature & Standard & Actual \\
\hline 1 & 34B19R & 40 C & MIN 2250 & 2600 \\
\hline 2 & 34B19R & 75 C & MIN 1100 & 1450 \\
\hline
\end{tabular}
Sumber : PT. XY Battery

\section{Perpindahan Panas Konduksi}

Konduksi adalah proses perpindahan panas yang terjadi jika panas mengalir dari tempat yang suhunya tinggi ke tempat yang suhunya lebih rendah, dengan media penghantar tetap. Secara umum, konduksi dirumuskan sebagai :

Atau,

$$
q=K A\left[\frac{d T}{d x}\right]
$$

$$
\frac{q}{A}=K\left[\frac{\Delta T}{\Delta x}\right]
$$

Dengan

$\begin{array}{llll}\mathrm{q} & : & \text { Laju perpindahan panas } & (\mathrm{J} / \mathrm{s} \text { atau } \mathrm{W}) \\ \mathrm{A} & : \text { Luas permukaan } & \left(\mathrm{m}^{2}\right) \\ \mathrm{k} & : & \text { Konduktivitas termal } & \left(\mathrm{W} / \mathrm{m}^{\circ} \mathrm{K}\right) \\ \Delta \mathrm{T}: & \text { Perubahan temperatur } & \left({ }^{\circ} \mathrm{C}\right) \\ \Delta \mathrm{x}: & \text { Tebal bahan } & (\mathrm{m})\end{array}$

Dalam konduksi kita mengenal istilah Konduktivitas Thermal (daya hantar panas) yaitu sifat bahan yang menunjukkan seberapa cepat suatu bahan menghantarkan panas konduksi. Pada umumnya nilai konduktivitas thermal (k) dianggap tetap, namun sebenarnya nilai k dipengaruhi oleh suhu $(\mathrm{T})$.

Bahan-bahan yang memiliki konduktivitas panas yang baik disebut konduktor, contohnya bahan logam. Dan bahan yang mempunyai konduktivitas panas tidak bagus disebut isolator, contohnya bahan non logam.

1. Konduksi Panas pada Satu Bidang Datar

Konduksi panas pada satu bidang datar dapat dirumuskan :

$$
\frac{q}{A}=K\left[\frac{\Delta T}{\Delta x}\right]
$$

Dan dapat di analogikan sebagai aliran listrik (Hukum Ohm) :

$$
I=\frac{V}{R}=>\quad q=-\frac{\Delta T}{\Delta x / k A}
$$

Tabel 2. Konduktivitas Termal

\begin{tabular}{|l|c||}
\hline \multicolumn{1}{|c|}{ Material Substance } & $\mathrm{k}(\mathrm{W} / \mathrm{m} \mathrm{K})$ \\
\hline Acrylic & 0,2 \\
\hline Alumunium & 205 \\
\hline Asbestos semen & 0,74 \\
\hline Brick & 0,15 \\
\hline Calsium Silicate & 0,05 \\
\hline Cartonplast & 0,158 \\
\hline Chromium & 94 \\
\hline Clay & $0,15-1,8$ \\
\hline Copper & 401 \\
\hline Cotton wool & 0,029 \\
\hline Fiberglass & 0,04 \\
\hline Glass, window & 0,96 \\
\hline Iron & 80 \\
\hline Leather & 0,14 \\
\hline Mica & 0,71 \\
\hline Nickel & 91 \\
\hline Plasticine & $0,65-0,8$ \\
\hline Polycarbonate & 0,19 \\
\hline Polyester & 0,05 \\
\hline Polyethylene & 0,33 \\
\hline Polypropylene & 0,22 \\
\hline Polystrene & 0,03 \\
\hline Polystyrol & 0,043 \\
\hline Polyurethane foam & 0,03 \\
\hline Porcelain & 1,5 \\
\hline Polyvinylchoride & 0,19 \\
\hline Rubber & 0,13 \\
\hline Silicone cast resin & $0,15-0,32$ \\
\hline Wool felt & 0,07 \\
\hline Zinc & 116 \\
\hline \hline Swmber|| \\
\hline
\end{tabular}

Sumber : www.EngineeringToolBox.com

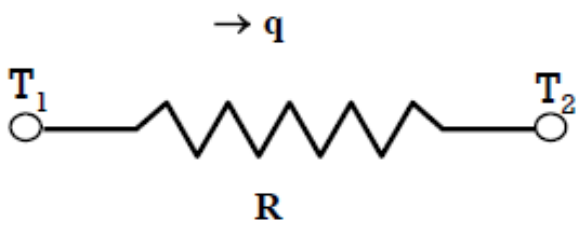

Gambar 2. Analogi Listrik pada Konduksi

Bila aliran dinyatakan dengan analogi listrik maka menjadi :

$$
\begin{gathered}
q=-\frac{\Delta T}{R}=-\frac{(T 2-T 1)}{\Delta x / k A} \\
q=\frac{\Delta T}{R}=\frac{T 1-T 2}{\Delta x / k A}
\end{gathered}
$$




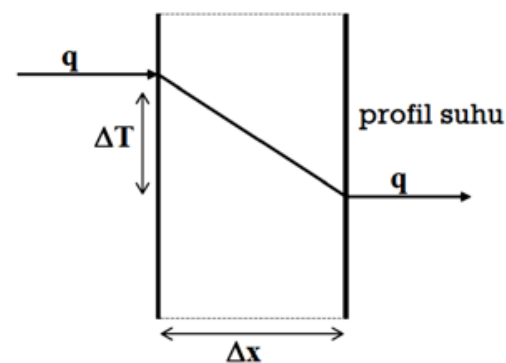

Gambar 3. Konduksi pada Satu Bidang Datar

2. Konduksi Panas pada Benda berlapis

Apabila aliran panas dilewatkan pada bidang datar yang disusun berlapis-lapis dengan bahan yang berbeda, maka konduksi panas ini dapat disebut dengan konduksi panas benda berlapis. Aliran panas masuk dengan suhu T1 dan keluar dengan suhu T4. Suhu antar muka masingmasingnya adalah T2 dan T3. Contohnya pada konstruksi furnace, boiler, dan lainnya.

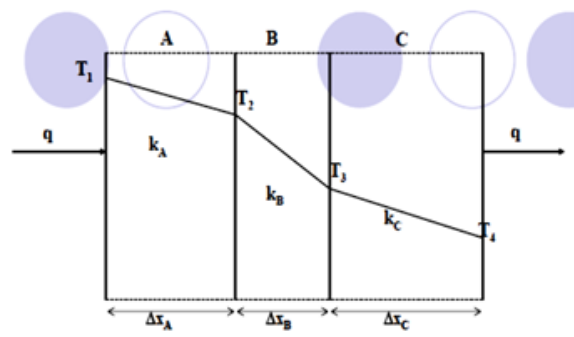

Gambar 4. Konduksi pada Benda Berlapis dan Tersusun Seri

Analogi listrik bahan yang disusun secara seri seperti gambar di atas ialah sebagai berikut :

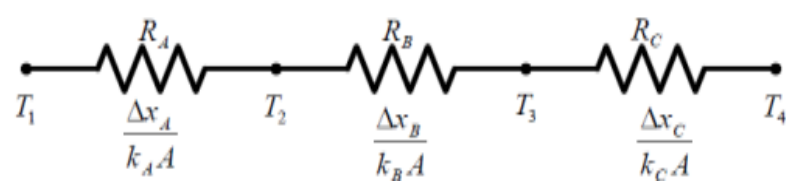

Gambar 5. Analogi Listrik pada Konduksi Benda Berlapis

Persamaan aliran panas untuk seluruh bidang datar adalah :

$$
q=\frac{\Delta T \text { menyeluruh }}{\sum R t h}
$$

Rth adalah jumlah tahanan thermal. Untuk bahannya yang disusun seri :

$$
\begin{aligned}
& q=\frac{\Delta T \text { menyeluruh }}{\sum R t h}=\frac{\Delta T}{\mathrm{R}_{\mathrm{A}}+\mathrm{R}_{\mathrm{B}}+\mathrm{R}_{\mathrm{C}}} \\
& q=\frac{T 1-T 4}{\frac{\Delta X A}{k A \cdot A}+\frac{\Delta X B}{k B \cdot A}+\frac{\Delta X C}{k C \cdot A}}
\end{aligned}
$$

Pada keadaan steady state, panas yang masuk pada sisi muka sebelah kiri harus sama dengan panas yang meninggalkan sisi muka sebelah kanan,
Sehingga,

$$
q \text { input }=q \text { output }
$$

$$
\begin{aligned}
& q=q A=q B=q C \\
& q=\frac{\Delta T}{\sum R t h}=\frac{\Delta T A}{\mathrm{R}_{\mathrm{A}}}+\frac{\Delta T B}{\mathrm{R}_{\mathrm{B}}}+\frac{\Delta T C}{\mathrm{R}_{\mathrm{C}}} \\
& q A=\frac{T 1-T 2}{\Delta x A / k A \cdot A} \\
& q B=\frac{T 2-T 3}{\Delta x B / k B \cdot A} \\
& q C=\frac{T 3-T 4}{\Delta x C / k C \cdot A}
\end{aligned}
$$

\section{Konveksi}

Konveksi adalah perpindahan panas karena adanya gerakan/ aliran/ percampuran dari bagian panas ke bagian yang dingin. Menurut cara menggerakkan alirannya, perpindahan panas konveksi diklasifikasikan

\begin{tabular}{|c|c|c|}
\hline q & Laju perpindahan panas & $(\mathrm{J} / \mathrm{s}$ atau $\mathrm{W})$ \\
\hline A & Luas permukaan & $\left(\mathrm{m}^{2}\right)$ \\
\hline $\mathrm{h}$ & Koefisien konveksi & $\left(\mathrm{W} / \mathrm{m}^{2}{ }^{\circ} \mathrm{K}\right)$ \\
\hline Tw & Temperatur dinding & $\left({ }^{\circ} \mathrm{C}\right)$ \\
\hline $\mathrm{T} \infty$ & Temperatur fluida & $\left({ }^{\circ} \mathrm{C}\right)$ \\
\hline
\end{tabular}
menjadi dua yakni konveksi bebas (free convection) dan konveksi paksa (forced convection). Bila gerakan fluida disebabkan karena adanya perbedaan kerapatan karena perbedaan suhu, maka perpindahan panasnya disebut konveksi bebas.

Secara umum, konveksi dapat dirumuskan:

$$
q=h A(T w-T \infty)
$$

dengan :

Tabel 3. Nilai koefisien konveksi udara dan air.

\begin{tabular}{lc}
\hline Conditions of heat transfer & W/( $\left.\mathrm{m}^{2} \mathrm{~K}\right)$ \\
\hline Gases in free convection & $5-37$ \\
Water in free convection & $100-1200$ \\
Oil under free convection & $50-350$ \\
Gas flow in tubes and between tubes & $10-350$ \\
Water flowing in tubes & $500-1200$ \\
Oil flowing in tubes & $300-1700$ \\
Molten metals flowing in tubes & $2000-45000$ \\
Water nucleate boiling & $2000-45000$ \\
Water film boiling & $100-300$ \\
Film-type condensation of water vapor & $4000-17000$ \\
Dropsize condensation of water vapor & $30000-140000$ \\
Condensation of organic liquids & $500-2300$ \\
\hline
\end{tabular}

Sumber : $w$ ww.thermopedia.com.

\section{Koefisien Perpindahan Panas Keseluruhan}

Perpindahan panas dapat terjadi pada sistem seperti gambar di bawah : 


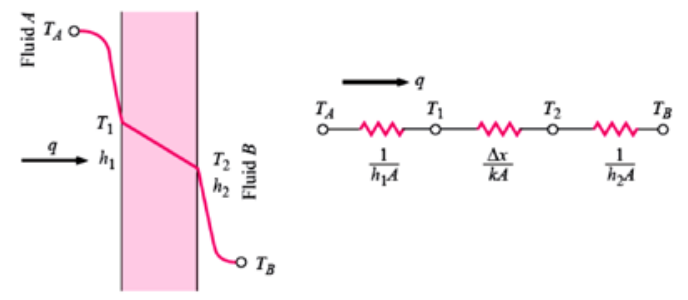

Gambar 5. Perpindahan Panas secara Keseluruhan

Perpindahan panas secara keseluruhan dapat dihitung sebagai perbanding perubahan temperatur secara keseluruhan dengan jumlah resistansi termal.

$$
q=\frac{T A-T B}{1 / h 1 A+\Delta x / k A+1 / h 2 A}
$$

Untuk mencari nilai h dari suatu fluida, dapat menggunakan persamaaan

$$
N u=\frac{h \cdot L}{K}
$$

Dimana :

$\mathrm{Nu}$ : Nusselt Number

h : Koefisien konveksi

L : Panjang benda

$\left(\mathrm{W} / \mathrm{m}^{20} \mathrm{~K}\right)$

K : Konduktivitas termal fluida

$\left(\mathrm{W} / \mathrm{m}^{\circ} \mathrm{K}\right)$

Bilangan Nusselt adalah rasio pindah panas konveksi dan konduksi normal terhadap batas dalam kasus pindah panas pada permukaan fluida. Bilangan ini tidak bersatuan. Komponen konduktif diukur di bawah kondisi yang sama dengan konveksi dengan kondisi fluida stagnan atau tidak bergerak. Untuk konveksi bebas, rataan bilangan Nusselt dinyatakan sebagai fungsi dari bilangan Rayleigh dan bilangan Prandtl. Dan untuk konveksi paksa, rataan bilangan Nusselt adalah fungsi dari bilangan Reynolds dan bilangan Prandtl. Hubungan empiris untuk berbagai geometri terkait konveksi menggunakan bialangan Nusselt didapatkan melalui eksperimen.

Bilangan Rayleigh dapat dicari dengan rumus :

$$
R a=G r \operatorname{Pr}=\frac{g \beta\left(T_{s}-T_{\infty}\right) L_{c}^{3}}{v^{2}} \frac{v}{\alpha}=\frac{g \beta\left(T_{s}-T_{\infty}\right) L_{c}^{3}}{v \alpha}
$$

Dimana :

$$
\begin{array}{lll}
\mathrm{g} & \text { : Gravitasi kecepatan } & (\mathrm{m} / \mathrm{s} 2) \\
\mathrm{v} & : \text { Kecepatan kinematik fluida } & \left(\mathrm{m}^{2} / \mathrm{s}\right) \\
\beta & : \text { Koefisien voulem ekspansi } & \left(\mathrm{K}^{-1}\right) \\
\alpha & \text { : Difusivitas thermal } & \left(\mathrm{m}^{2} / \mathrm{s}\right) \\
\mathrm{k} & : \text { Kondukitivitas termal fluida } & \left(\mathrm{W} / \mathrm{m}{ }^{0} \mathrm{~K}\right) \\
\mathrm{L} & \text { : Panjang geometri benda } & (\mathrm{m})
\end{array}
$$

$\mathrm{Ra} \leq 10^{9}$ maka aliran fluida adalah laminer sedangkan $\mathrm{Ra} \geq 10^{9}$ maka aliran fluida adalah turbulen. Bilangan Nusselt dapat dicari dengan

$$
N u=\frac{h \cdot L}{K}=\mathrm{C} . \mathrm{Ra}^{\mathrm{n}}
$$

\section{METODOLOGI PENELITIAN}

Metodologi penelitian ini merupakan langkahlangkah yang dilakukan dalam melaksanakan sebuah penelitian. Metodologi penelitian dalam pembuatan skripsi ini dapat digambarkan dalam diagram alir seperti berikut ini:

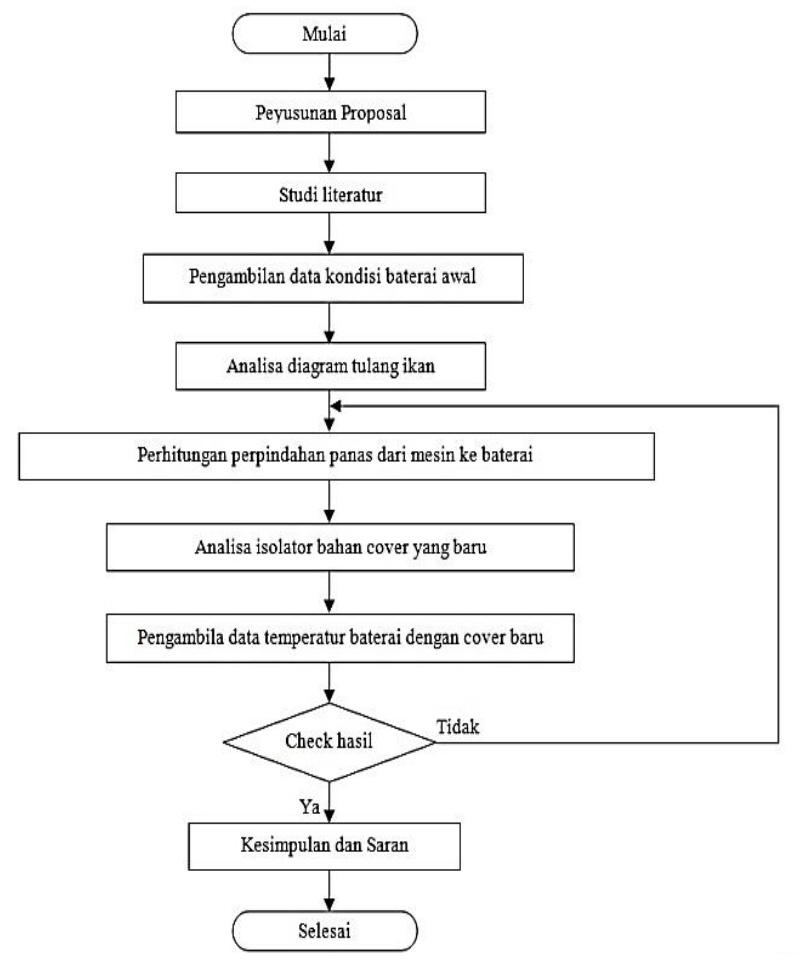

Gambar 6. Diagram Alir Penelitian

\section{Identifikasi Masalah}

Identifikasi masalah awal dlakukan menggunakan analisa diagram tulang ikan, disebut juga cause and effect diagram merupakan sebuah alat yang digunakan untuk mengidentifikasi dan menunjukkan hubungan antara sebab dan akibat agar dapat menemukan akar penyebab dari suatu permasalahan. Metode ini pertama kali diperkenalkan oleh Prof. Kaoru Ishikawa dari Universitas Tokyo di tahun 1953 dan telah digunakan di beberapa perusahaan Jepang.

Pada diagram tulang ikan terdapat lima aspek yang mewakili kemungkinan akar suatu masalah, yaitu dari segi man, material, methode, machine, dan environment. Berikut adalah kemungkinan berusakan baterai dari beberapa aspek :

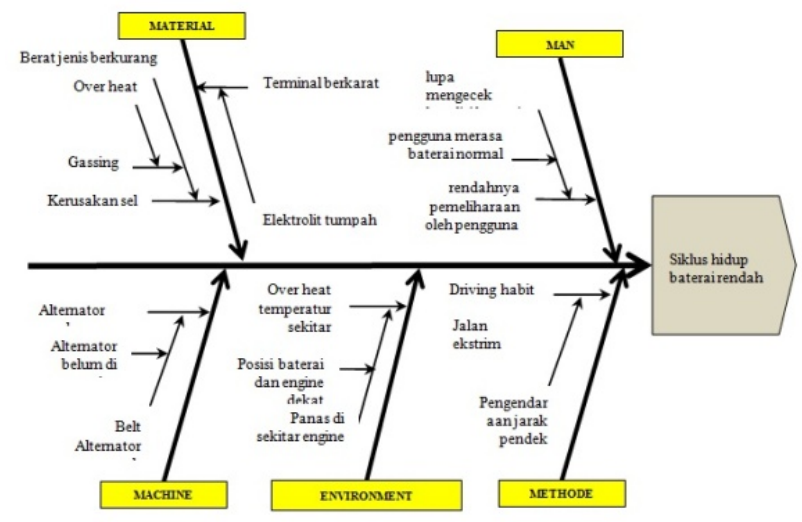

Gambar 7. Diagram Tulang Ikan 


\section{Prosedur Pengambilan data}

Lama

Temperatur Cairan Baterai dengan Cover

Tempat pengambilan data : Gedung Riset dan

Pengembangan

Waktu pengambilan data $: 09.00-16.00$ WIB

Kondisi pengambilan data :

1. Temperatur lingkungan sekitar $28-30^{\circ} \mathrm{C}$.

2. Kondisi mobil idle kecepatan $\pm 980 \mathrm{rpm}$.

3. Kondisi AC on maximal dingin, kaca jendela dibuka sepertiga untuk menjaga perputaran suhu.

4. Mobil di tempatkan di bawah pepohonan.

Besaran yang diamati

1. Temperatur ruang mesin selama 180 menit, dicatat selama lima belas menit.

2. Temperatur cairan baterai selama 180 menit, dicatat selama lima belas menit.

Pengaturan dan Pemasangan Alat Ukur

1. Tempelkan kabel 1 ke sisi luar cartonplast

2. Tempelkan kabel 2 ke sisi luar dinding baterai

3. Lubangi kap ventilasi baterai dan masukan alat ke dalam cairan baterai. Tutup lubang yang masih terlihat sehingga tidak ada panas yang keluar.

4. Atur kabel 4 di dalam ruang mesin

5. Atur channel pembacaan temperatur dari hioki dengan :

Channel 1 : Temperatur ruang engine

Channel 2 : Temperatur cartonplast

Channel 3 : Temperatur dinding baterai

Channel 4 : Temperatur cairan baterai

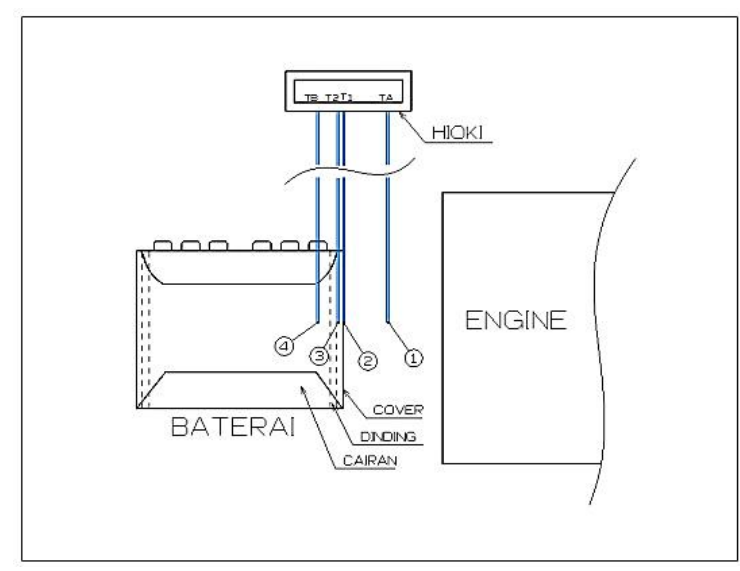

Gambar 8. Kondisi Pengukuran Baterai dengan Cover Lama

6. Tutup engine hood dan tempelkan kabel ke badan mobil sehingga kabel tidak berantakan.

7. Masukkan hioki ke dalam kabin mobil.

Temperatur Cairan Baterai dengan Cover
Tempat pengambilan data : Jakarta - PadalarangPuncak

Waktu pengambilan data $: 09.00-14.00 \mathrm{WIB}$

Kondisi pengambilan data :

1. Temperatur lingkungan sekitar $29-32,5^{\circ} \mathrm{C}$.

2. Kondisi mobil running di jalanan Jakarta Padalarang - Puncak

3. Kondisi AC on, kaca jendela dibuka sepertiga untuk menjaga perputaran suhu.

Point yang diamati :

1. Temperatur ruang mesin selama 300 menit, dicatat selama lima belas menit.

2. Temperatur cairan baterai selama 300 menit, dicatat selama lima belas menit.

Pengaturan dan Pemasangan Alat Ukur

1. Tempelkan kabel 1 ke sisi luar cartonplast

2. Tempelkan kabel 2 ke sisi dalam cartonplast (Foam)

3. Tempelkan kabel 3 ke sisi luar dinding baterai

4. Lubangi cap ventilasi baterai dengan bor dan masukan alat ukur ke sampai masuk ke dalam cairan baterai. Tutup lubang yang masih terlihat sehingga tidak ada panas yang keluar.

5. Atur kabel 4 di dalam ruang engine

6. Atur channel pembacaan temperatur dari hioki dengan :

Channel 1 : Temperatur ruang engine

Channel 2 : Temperatur cartonplast sisi luar

Channel 3 : Temperatur cartonplast sisi dalam (Foam)

Channel 4 : Temperarur dinding Baterai sisi luar

Channel 5 : Temperatur cairan baterai

7. Tutup engine hood dan tempelkan kabel ke badan mobil sehingga kabel tidak berantakan.

8. Masukkan hioki ke dalam kabin mobil.

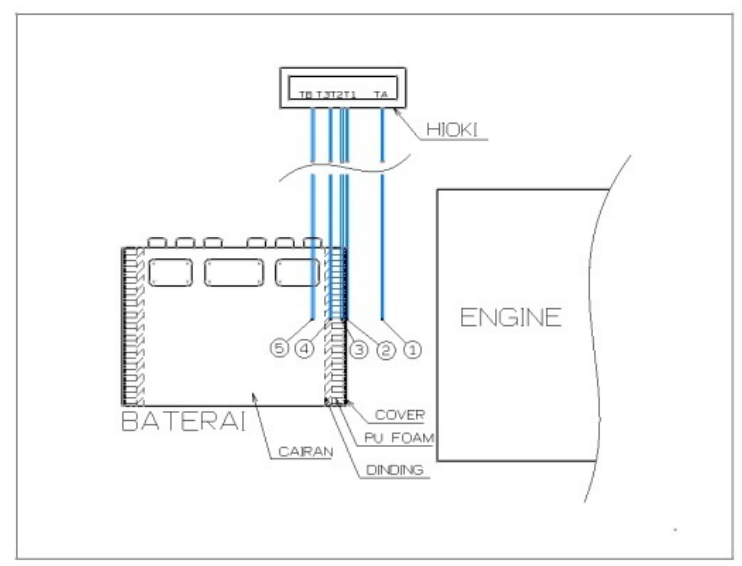

Gambar 9. Kondisi Pengukuran Baterai dengan Cover Baru

Baru 


\section{Alat dan Bahan}

Tabel 4. Alat dan Bahan Penelitian

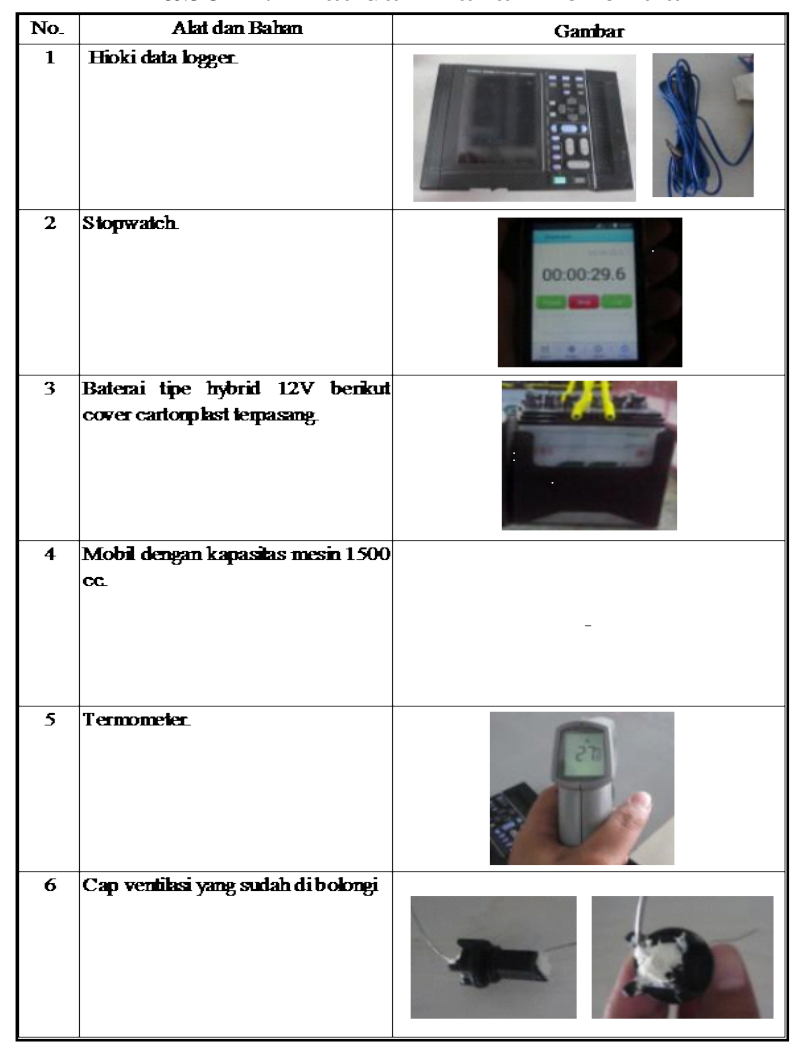

\section{Spesifikasi Bahan Cover dan Baterai Lama}

Bahan yang digunakan dalam penelitian adalah Cover Baterai dari cartonplast, dan kotak baterai dengan material Polypropylene (PP).

Tabel 5. Spesifikasi Bahan Penelitian

\begin{tabular}{|l|l|c|c|c|}
\hline \multicolumn{1}{|c|}{ Nama } & \multicolumn{1}{c|}{ Bahan } & $\mathrm{K}(\mathrm{W} / \mathrm{m} \mathrm{K})$ & $\mathrm{t}(\mathrm{mm})$ & $\mathrm{L}(\mathrm{m})$ \\
\hline Cover Baterai & Cartonplast & 0,158 & 2,5 & 0,117 \\
\hline Isolasi & Polyurethane & 0,03 & 7,5 & 0,117 \\
\hline Kotak Baterai & Polypropylene & 0,22 & 5 & 0,177 \\
\hline
\end{tabular}

\section{Pengolahan Data dan Perhitungan}

Lama

Perhitungan Perpindahan Panas pada Cover

Tabel 6. Pengukuran Temperatur Baterai dengan Cover Lama

\begin{tabular}{|c|c|c|c|c|}
\hline \multirow[b]{2}{*}{$\begin{array}{c}\text { time } \\
\text { (minute) }\end{array}$} & \multicolumn{4}{|c|}{ PENGUKURAN TEMPERATUR (C) } \\
\hline & $\begin{array}{c}\text { Ruang mesin } \\
\text { [TA] }\end{array}$ & $\begin{array}{c}\text { Cartonplast } \\
\text { [T1] }\end{array}$ & $\begin{array}{c}\text { Dinding } \\
\text { Baterai [T2] }\end{array}$ & $\begin{array}{c}\text { Cairan } \\
\text { baterai [TB] }\end{array}$ \\
\hline start & 29,8 & 27,2 & 26,9 & 26 \\
\hline 15 & 57 & 36,2 & 34,2 & 29,2 \\
\hline 30 & 65,5 & 39,7 & 37,1 & 32,1 \\
\hline 45 & 69,7 & 42,8 & 41,2 & 37 \\
\hline 60 & 70,4 & 49,4 & 46,8 & 42,7 \\
\hline 75 & 70,6 & 54,4 & 52,2 & 47,3 \\
\hline 90 & 67,3 & 55,9 & 54,8 & 51,2 \\
\hline 105 & 66,1 & 59,7 & 58 & 53,8 \\
\hline 120 & 66,9 & 62,7 & 60,4 & 56,7 \\
\hline 135 & 69,9 & 63,4 & 62,1 & 58,7 \\
\hline 150 & 70,2 & 64,7 & 63,2 & 60,4 \\
\hline 165 & 69,9 & 66,6 & 64,4 & 60,7 \\
\hline 180 & 69,8 & 68,9 & 67,3 & 64,4 \\
\hline
\end{tabular}

Perhitungan konduksi

Pada menit ke 180, diketahui :

$\mathrm{T} 1 \quad$ : $\quad 68,9{ }^{\circ} \mathrm{C}=341,9^{\circ} \mathrm{K}$

$\mathrm{T} 2 \quad: \quad 67,3{ }^{\circ} \mathrm{C}=340,3{ }^{\circ} \mathrm{K}$

$\Delta \mathrm{T} 1: \mathrm{T} 1-\mathrm{T} 2$

$$
\text { : } \quad 341,9{ }^{\circ} \mathrm{K}-340,3{ }^{\circ} \mathrm{K}=1,6{ }^{\circ} \mathrm{K}
$$

$\Delta \mathrm{x} 1: 2,5 \mathrm{~mm}=0,0025 \mathrm{~m}$

$\mathrm{k} 1 \quad$ : cartonplast $=0,158 \mathrm{~W} / \mathrm{m}{ }^{\circ} \mathrm{K}$

$q 1=\quad k \cdot A \frac{\Delta T 1}{\Delta x 1}$

$\frac{q 1}{A}=0,158 \mathrm{~W} / \mathrm{mK} \cdot \frac{1,6 \mathrm{~K}}{0,0025 \mathrm{~m}}$

$\frac{q 1}{A}=101,1 \mathrm{~W} / \mathrm{m}^{2}$

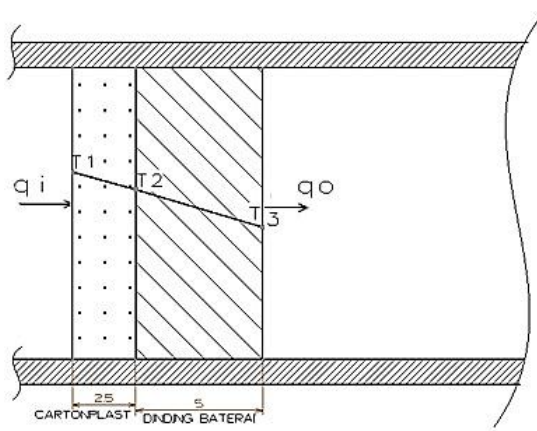

Gambar 10. Konduksi Lapis Seri pada Baterai

Besarnya laju perpindahan panas pada Cartonplast adalah sebesar 101,1 W/ $\mathrm{m}^{2}$.

Untuk mengetahui T3 atau Temperatur Dinding Baterai bagian Dalam, maka dapat dihitung sebagai berikut :

$\frac{q 1}{A}=\frac{q 2}{A}$

$101,1 \mathrm{~W}=q 2$

$101,1 \mathrm{~W}=\frac{\Delta T 2}{R 2}$

Diketahui dari pengukuran :

T2 : $\quad 67,3{ }^{\circ} \mathrm{C}=340,3{ }^{\circ} \mathrm{K}$

$\Delta \mathrm{T} 2: \mathrm{T} 2-\mathrm{T} 3$

$\Delta \mathrm{x} 2 \quad: \quad 5,0 \mathrm{~mm}=0,005 \mathrm{~m}$

$\mathrm{k} 2 \quad: \quad \mathrm{PP}=0,22 \mathrm{~W} / \mathrm{m}{ }^{\circ} \mathrm{K}$

maka,

$q 2=k \cdot A \frac{\Delta T 2}{\Delta x 2}$

$\frac{q 1}{A}=\frac{q 2}{A}$

$\mathrm{q} 1=0,22 \mathrm{~W} / \mathrm{mK} \cdot \frac{\Delta \mathrm{T} 2}{0,005 \mathrm{~m}}$

$\Delta \mathrm{T} 2=2,7 \mathrm{~K}$

$\Delta \mathrm{T} 2=\mathrm{T} 2-\mathrm{T} 3$

$2,7^{\circ} \mathrm{K}=340,3{ }^{\circ} \mathrm{K}-\mathrm{T} 3$

$\mathrm{T} 3=340,3{ }^{\circ} \mathrm{K}-2,7{ }^{\circ} \mathrm{K}=338{ }^{\circ} \mathrm{K}=65{ }^{\circ} \mathrm{C}$

$\sum \mathrm{R}$ th $=\mathrm{R} 1+\mathrm{R} 2$

$\sum$ Rth $=\frac{\Delta \mathrm{x} 1}{\mathrm{k} 1}+\frac{\Delta \mathrm{x} 2}{\mathrm{k} 2}=\frac{0,0025 \mathrm{~m}}{0,158 \mathrm{~W} / \mathrm{mK}}+\frac{0,005 \mathrm{~m}}{0,22 \mathrm{~W} / \mathrm{mK}}$ $=0,0386 \mathrm{~K} \cdot \mathrm{m}^{2} / \mathrm{W}$

qcond $=\frac{\Delta T}{\sum \text { Rth }}=\frac{T 1-T 3}{\sum \text { Rth }}$ 
$\begin{aligned} \text { qcond } & =\frac{341,9 K-338 K}{0,0386 \mathrm{~K} \cdot \mathrm{m} 2 / \mathrm{W}} \\ \text { qcond } & =101,1 \mathrm{~W} / \mathrm{m}^{2} .\end{aligned}$

Perhitungan Konveksi dan Perpindahan Panas Menyeluruh

Besarnya laju perpindahan panas menyeluruh dapat dicari :

$$
q=\frac{T A-T B}{1 / h 1 A+\Delta x / k A+\Delta x / k A+1 / h 2 A}
$$

Untuk mengetahui nilai koefisien perpindahan panas konveksi udara dan cairan baterai, maka digunakan rumus :

$$
N u=\frac{h \cdot L}{K}
$$

Dan nilai dari bilangan nusselt dapat dicari dengan persamaan di bawah :

$$
N u=\frac{h \cdot L}{K}=\mathrm{C} \cdot \mathrm{Ra}^{\mathrm{n}}
$$

Dengan nilai Ra dirumuskan :

$$
R a=G r \operatorname{Pr}=\frac{g \beta\left(T_{s}-T_{\infty}\right) L_{c}^{3}}{v^{2}} \frac{v}{\alpha}=\frac{g \beta\left(T_{s}-T_{\infty}\right) L_{c}^{3}}{v \alpha}
$$

Maka pada menit ke 180, dengan temperatur udara terukur (TA) $69,8{ }^{\mathrm{O}} \mathrm{C}$ atau $342,8{ }^{\mathrm{O}} \mathrm{K}$, didapatkan sifat udara pada tabel termodinamika :

$$
\begin{array}{ll}
\mathrm{g} & =10 \mathrm{~m} / \mathrm{s}^{2} \\
\mathrm{v} & =2,0 \times 10^{-5} \mathrm{~m}^{2} / \mathrm{s} \\
\beta & =2,89 \times 10^{-3} \mathrm{~K}^{-1} \\
\alpha & =2,8 \times 10^{-6} \mathrm{~m}^{2} / \mathrm{s} \\
\mathrm{k} & =29 \times 10^{-3} \mathrm{~W} / \mathrm{m}^{0} \mathrm{~K} \\
\mathrm{~L} & =0,117 \mathrm{~m} \\
\text { Tudara } & =342,8 \mathrm{~K} \\
\text { T1 } & =341,9 \mathrm{~K}
\end{array}
$$

Maka dengan persamaan Rayleigh dapat dicari:

$$
\begin{aligned}
& R a=G r \operatorname{Pr}=\frac{g \beta\left(T_{s}-T_{\infty}\right) L_{c}^{3}}{v^{2}} \frac{v}{\alpha}=\frac{g \beta\left(T_{s}-T_{\infty}\right) L_{c}^{3}}{v \alpha} \\
& \mathrm{Ra} \quad=\frac{10.2,89 \times 10^{-3}(342,8-341,9)(0,117)^{3}}{12,0 \times 10^{-5} \cdot 2,8 \times 10^{-5}} \\
& \mathrm{Ra}=7,3 \times 10^{8} \leq 10^{9}
\end{aligned}
$$

Aliran fluida adalah laminer maka nilai :

$$
\mathrm{n} \quad=1 / 4
$$$$
\text { c } \quad=0,59
$$

$$
\begin{gathered}
N u=\frac{h 1 \cdot L}{K 1}=\mathrm{C} \cdot \mathrm{Ra}^{\mathrm{n}} \\
N u=\frac{h 1 \cdot L}{K 1}=0,59 \cdot\left(7,3 \times 10^{8}\right)^{1 / 4} \\
N u=\frac{h 1 \cdot L}{K 1}=93,7
\end{gathered}
$$

Maka dapat dicari nilai h :

$$
\begin{aligned}
93,7 & =\frac{h 1 \cdot 0,117 m}{0,029 \mathrm{~W} / \mathrm{m} \mathrm{K}} \\
h 1 & =24,4 \mathrm{~W} / \mathrm{m}^{2} \mathrm{~K}
\end{aligned}
$$

untuk fluida cairan baterai, diasumsikan sifat fisik air pada temperatur (TB) $64,4{ }^{\circ} \mathrm{C}$ atau $337,4{ }^{\circ} \mathrm{K}$, maka diketahui :

$$
\begin{array}{ll}
\mathrm{g} & =10 \mathrm{~m} / \mathrm{s}^{2} \\
\mathrm{v} & =4,5 \times 10^{-7} \mathrm{~m}^{2} / \mathrm{s}
\end{array}
$$

$$
\begin{array}{ll}
\beta & =2,9 \times 10^{-3} \mathrm{~K}^{-1} \\
\alpha & =1,5 \times 10^{-7} \mathrm{~m}^{2} / \mathrm{s} \\
\mathrm{k} & =0,654 \mathrm{~W} / \mathrm{m}^{0} \mathrm{~K} \\
\mathrm{~L} & =0,117 \mathrm{~m} \\
\text { Tair } & =337,4 \mathrm{~K} \\
\text { T3 } & =338 \mathrm{~K}
\end{array}
$$

Maka dengan persamaan Rayleigh dapat dicari:

$$
\begin{aligned}
& \mathrm{Ra}=\frac{10 \cdot 2,9 \times 10^{-3} \cdot(337,4-338)^{0} \cdot(0,117)^{3}}{4,5 \times 10^{-7} \cdot 1,5 \times 10^{-7}} \\
& =385583301=3,85 \times 10^{8} \leq 10^{9} \\
& N u=\frac{h 2 . L}{K 2}=\mathrm{C} . \mathrm{Ra}^{\mathrm{n}} \\
& N u=\frac{h 2 \cdot L}{K 2}=0,59 \cdot 3,85 \times 10^{81 / 4} \\
& N u=\frac{h 2 . L}{K 2}=82,67
\end{aligned}
$$

Maka dapat dicari nilai h :

$$
\begin{gathered}
82,67=\frac{h 2 \cdot 0,117 m}{0,654 \mathrm{~W} / \mathrm{m} \mathrm{K}} \\
h 2=462,6 \mathrm{~W} / \mathrm{m}^{2} \mathrm{~K}
\end{gathered}
$$

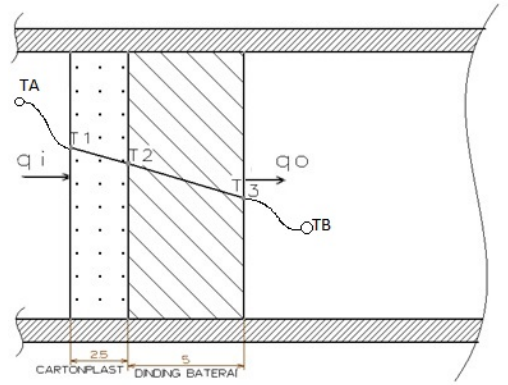

Gambar 11. Laju Perpindahan Panas Menyeluruh

Maka besarnya laju perpindahan panas menyeluruh ialah :

$$
\begin{aligned}
q & =\frac{T A-T B}{1 / h 1 A+\Delta x 1 / k 1 A+\Delta x 2 / k 2 A+1 / h 2 A} \\
q & =\frac{T A-T B}{1 / h 1+\sum R t h+1 / h 2}
\end{aligned}
$$

Dimana TA dan TB dari pengukurun sebagai berikut :

$$
\begin{aligned}
\mathrm{TA} & =342,8 \mathrm{~K} \\
\mathrm{~TB} & =337,4 \mathrm{~K} \\
\mathrm{~h} 1 & =24,4 \mathrm{~W} / \mathrm{m}^{2} . \mathrm{K} \\
\mathrm{h} 2 & =462,6 \mathrm{~W} / \mathrm{m}^{2} . \mathrm{K} \\
\sum \text { Rth } & =0,0386 \mathrm{~K} \mathrm{~m} / \mathrm{W}
\end{aligned}
$$

$$
q=\frac{(342,8-337,4) K}{\frac{1}{24,4 W / m 2 K}+0,0386 \mathrm{Km} 2 / W+\frac{1}{462 W / m 2 K}}
$$

Perhitungan Tebal Isolasi Cover Baterai 
Berdasarkan gambar konduksi lapisan seri di bawah, dengan temperatur dinding baterai bagian dalam (T4) dipertahankan $40^{\circ} \mathrm{C}$, maka dapat dicari:

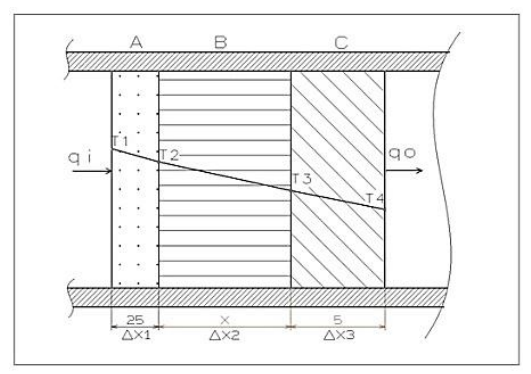

Gambar 12. Penambahan Isolasi Cover

$$
\begin{aligned}
& \text { T4 : } 40{ }^{\circ} \mathrm{C}=313{ }^{\circ} \mathrm{K} \\
& \Delta \mathrm{x} 3 \quad: 5,0 \mathrm{~mm}=0,005 \mathrm{~m} \\
& \text { k3 : } \mathrm{PP}=0,22 \mathrm{~W} / \mathrm{m}^{\circ} \mathrm{K} \\
& 101,1 \mathrm{~W} / \mathrm{m}^{2}=q 3 \\
& 101,1 \mathrm{~W} / \mathrm{m}^{2}=\mathrm{K} 3 \frac{\Delta T 3}{\Delta x 3} \\
& 101,1 \mathrm{~W} / \mathrm{m}^{2}=0,22 \mathrm{~W} / \mathrm{m}^{\circ} \mathrm{K} \frac{\Delta T 3}{0,005 \mathrm{~m}} \\
& \left(\mathrm{~T} 3-313{ }^{\circ} \mathrm{K}\right)=2,29 \mathrm{~K} \\
& \mathrm{~T} 3=2,29+313{ }^{\circ} \mathrm{K} \\
& \mathrm{T} 3=315,3{ }^{\circ} \mathrm{K} \\
& \mathrm{T} 3=42,29^{\circ} \mathrm{C} \\
& \mathrm{T} 2-\mathrm{T} 3=340,3{ }^{\circ} \mathrm{K}-315,3{ }^{\circ} \mathrm{K} \\
& \mathrm{T} 2-\mathrm{T} 3=25^{\circ} \mathrm{K} \text {. } \\
& \Delta \mathrm{T} 2 \quad=25{ }^{\circ} \mathrm{K}
\end{aligned}
$$

Dengan nilai K Polyurethane : 0,03 W/ m K, maka dapat dicari

$$
\begin{array}{ll}
\mathrm{q} 1 & =\mathrm{q} 2 \\
101,12 \mathrm{~W} / \mathrm{m} 2 & =\mathrm{K} 2 \frac{\Delta T 2}{\Delta x 2} \\
101,12 \mathrm{~W} / \mathrm{m} 2 & =0,003 \mathrm{~W} / \mathrm{mK} \frac{25 K}{\Delta x 2} \\
\Delta \mathrm{X} 2 & =0,0074 \mathrm{~m}=7,4 \mathrm{~mm} \\
\sum \text { Rth } & =\mathrm{R} 1+\mathrm{R} 2+\mathrm{R} 3 \\
\sum \text { Rth } & =\frac{\Delta x 1}{\mathrm{k} 1}+\frac{\Delta \mathrm{x} 2}{\mathrm{k} 2}+\frac{\Delta \mathrm{x} 3}{\mathrm{k} 3} \\
\sum \text { Rth } & =\quad \frac{0,0025 \mathrm{~m}}{0,158 \mathrm{~W} / \mathrm{mK}}+\frac{0,005 \mathrm{~m}}{0,22 \mathrm{~W} / \mathrm{mK}} \\
+\frac{0,074 \mathrm{~m}}{0,03 \mathrm{~W} / \mathrm{mK}} & \\
\sum \mathrm{Rth} & =0,289 \mathrm{~K} \cdot \mathrm{m}^{2} / \mathrm{W}
\end{array}
$$

Besarnya $\sum$ Rth pada cover dengan penambahan isolasi adalah: $0,289 \mathrm{Km}^{2} / \mathrm{W}$.

Perhitungan Perpindahan Panas pada Cover Baru
Tabel 7. Pengukuran Temperatur Baterai dengan Cover Baru

\begin{tabular}{|c|c|c|c|c|c|c|}
\hline \multirow{2}{*}{$\begin{array}{c}\text { time } \\
\text { (minute) }\end{array}$} & Lingkungan & $\begin{array}{c}\text { Ruang } \\
\text { mesin [TA] }\end{array}$ & $\begin{array}{c}\text { Cartonplast } \\
{[\text { T1] }}\end{array}$ & $\begin{array}{c}\text { PU } \\
{[\mathrm{T} 2]}\end{array}$ & $\begin{array}{c}\text { Dinding } \\
\text { baterai } \\
{[\mathrm{T} 3]}\end{array}$ & $\begin{array}{c}\text { Cairan } \\
\text { baterai } \\
{[\mathrm{TB}]}\end{array}$ \\
\hline start & 29 & 36,2 & 33,9 & 31,9 & 29,9 & 26,2 \\
\hline 15 & 29,5 & 49,1 & 46,7 & 45,1 & 35,1 & 29,4 \\
\hline 30 & 31 & 61 & 58 & 55,8 & 34 & 30 \\
\hline 45 & 31,2 & 66,7 & 63,7 & 61,7 & 38,7 & 34,7 \\
\hline 60 & 31 & 62,6 & 58,6 & 57,4 & 36,6 & 32,9 \\
\hline 75 & 32,3 & 70,2 & 66,4 & 65 & 42,4 & 38,2 \\
\hline 90 & 30 & 56,1 & 52,9 & 51,1 & 37,9 & 34,4 \\
\hline 105 & 32,3 & 69,9 & 66,3 & 65 & 41,3 & 37,6 \\
\hline 120 & 32 & 62,4 & 59,3 & 58,1 & 39,3 & 36,5 \\
\hline 135 & 30 & 62,7 & 59,5 & 58,4 & 39,5 & 36,5 \\
\hline 150 & 28,9 & 59,7 & 56,7 & 55,6 & 37,7 & 33,7 \\
\hline 165 & 31,2 & 70,1 & 66,6 & 65,5 & 44,6 & 40,6 \\
\hline 180 & 31,5 & 72,4 & 69,1 & 67,9 & 47,1 & 43,1 \\
\hline 195 & 31 & 74,5 & 71,4 & 70,5 & 49,4 & 45,4 \\
\hline 210 & 31 & 73,7 & 70,5 & 69,5 & 46,5 & 42,4 \\
\hline 225 & 31 & 60,9 & 57,9 & 56,8 & 37,9 & 34,9 \\
\hline 240 & 31,4 & 65,4 & 62,4 & 61,3 & 42,4 & 38,4 \\
\hline 255 & 31,2 & 68,1 & 65 & 63,9 & 43 & 39,8 \\
\hline 270 & 31,5 & 71 & 67,6 & 66,5 & 44,6 & 40 \\
\hline 285 & 31 & 71,7 & 68,3 & 67,2 & 43,3 & 39,3 \\
\hline 300 & 28,7 & 64,3 & 61,1 & 60 & 39,1 & 37,1 \\
\hline & & & & & & \\
\hline
\end{tabular}

Dari data pengukuran untuk cover baru, dapat dicari nilai q pada menit ke 300 :

$\mathrm{T} 1 \quad$ : $61,1{ }^{\circ} \mathrm{C}=334,1^{\circ} \mathrm{K}$

$\mathrm{T} 2: 60{ }^{\circ} \mathrm{C}=333{ }^{\circ} \mathrm{K}$

$\Delta \mathrm{T} 1 \quad \mathrm{~T} 1-\mathrm{T} 2$

$$
\text { : } 334,1{ }^{\circ} \mathrm{K}-333^{\circ} \mathrm{K}=1,1^{\circ} \mathrm{K}
$$

$\mathrm{K} 1 \quad: \quad 0,158 \mathrm{~W} / \mathrm{m} \mathrm{K}$

$\Delta \mathrm{X} 1 \quad$ : $0,0025 \mathrm{~m}$

Maka,

$q 1=K 1 \cdot A \frac{\Delta T 1}{\Delta X 1}$

$\frac{q 1}{A}=0,158 \mathrm{~W} / \mathrm{mK} \frac{1,1 \mathrm{~K}}{0,0025}$

$\frac{q 1}{A}=69,5 \mathrm{~W} / \mathrm{m}^{2}$

Untuk nilai q2 adalah :

$q 2=K 2 . A \frac{\Delta T 2}{\Delta X 2}$

$\mathrm{T} 2 \quad: \quad 60{ }^{\circ} \mathrm{C} \quad=333{ }^{\circ} \mathrm{K}$

T3 : $39,1{ }^{\circ} \mathrm{C}=312,1{ }^{\circ} \mathrm{K}$

$\Delta \mathrm{T} 2 \quad: \quad \mathrm{T} 1-\mathrm{T} 2$

$\mathrm{K} 2: 0,03 \mathrm{~W} / \mathrm{m} \mathrm{K}$

$\Delta \mathrm{X} 2: 0,0074 \mathrm{~W} / \mathrm{mK}$

Maka,

$q 2=K 2 \cdot A \frac{\Delta T 2}{\Delta X 2}$

$\frac{q 2}{A}=0,03 \mathrm{~W} / \mathrm{mK} \frac{20,9 \mathrm{~K}}{0,0074}$

$\frac{q 2}{A}=83,6 \mathrm{~W} / \mathrm{m}^{2}$

Dengan demikian didapatkan nilai T4 sebagai berikut : 


$$
\begin{array}{ll}
\frac{q 2}{A}=\frac{q 3}{A} & \\
\mathrm{~K} 3 & : 0,22 \mathrm{~W} / \mathrm{m} \mathrm{K} \\
\Delta \mathrm{X} 3 & : 0,005 \mathrm{~W} / \mathrm{mK} \\
83,6 \mathrm{~W} / \mathrm{m}^{2} & =\mathrm{K} 3 \cdot \mathrm{A} \cdot \frac{\Delta T 3}{\Delta X 3} \\
83,6 \mathrm{~W} / \mathrm{m}^{2} & =0,22 \mathrm{~W} / \mathrm{mK} \cdot \frac{T 3-T 4}{0,005 m} \\
\mathrm{~T} 4 & =310,2^{\circ} \mathrm{K} \\
\mathrm{T} 4 & =37,2{ }^{\circ} \mathrm{C}
\end{array}
$$

Dengan demikian, dapat di cari q total konduksi pada cover baru adalah :

$$
\begin{aligned}
\text { qcond } & =\frac{T 1-T 4}{\sum R t h} \\
\text { qcond } & =\frac{T 1-T 4}{R 1+R 2+R 3} \\
\text { qcond } & =\frac{334,1 \mathrm{~K}-310,2 \mathrm{~K}}{(0,0158+0,250+0,023) \mathrm{Km} 2 / W} \\
\text { qcond } & =82,87 \mathrm{~W} / \mathrm{m}^{2} .
\end{aligned}
$$

Besarnya hambatan termal pada cover baru adalah $\sum$ Rth $0,289 \mathrm{~K} / \mathrm{W} \mathrm{m}^{2}$.

Mencari nilai h udara disekitar mesin :

Diketahui dari tabel sifat udara pada suhu $64,3{ }^{\circ} \mathrm{C}$ atau $337,3^{\circ} \mathrm{K}$

$$
\begin{aligned}
\mathrm{g} & =10 \mathrm{~m} / \mathrm{s}^{2} \\
\mathrm{v} & =1,9 \times 10^{-5} \mathrm{~m}^{2} / \mathrm{s} \\
\beta & =2,96 \times 10^{-3} \mathrm{~K}^{-1} \\
\alpha & =2,8 \times 10^{-5} \mathrm{~m}^{2} / \mathrm{s} \\
\mathrm{k} & =29 \mathrm{~W} / \mathrm{m}^{0} \mathrm{~K} \\
\mathrm{~L} & =0,117 \mathrm{~m} \\
\mathrm{Tw} & =337,3 \mathrm{~K} \\
\mathrm{~T} \sim & =334,1 \mathrm{~K}
\end{aligned}
$$

Maka dengan persamaan Rayleigh dapat dicari:

$$
\begin{aligned}
\mathrm{Ra} & =\frac{10 \cdot 2,9 \times 10^{-3}(337,3-334,1) \cdot(0,117)^{3}}{1,9 \times 10^{-5} \cdot 2,8 \times 10^{-5}} \\
\text { Ra } & =1,7 \times 10^{8} \leq 10^{9}
\end{aligned}
$$$$
\text { Aliran fluida adalah laminer maka nilai : }
$$

$$
\begin{array}{ll}
\mathrm{n} & =1 / 4 \\
\mathrm{C} & =0,59
\end{array}
$$

$$
\begin{aligned}
N u & =\frac{h 1 \cdot L}{K 1}=\mathrm{C} \cdot \mathrm{Ra}^{\mathrm{n}} \\
N u=\frac{h 1 \cdot L}{K 1} & =0,59 \cdot\left(1,7 \times 10^{8}\right)^{1 / 4} \\
N u & =\frac{h 1 \cdot L}{K 1}=67,67
\end{aligned}
$$

Maka dapat dicari nilai $\mathrm{h}$ :

$$
\begin{aligned}
& 67,67=\frac{h 1 \cdot 0,117 \mathrm{~m}}{29 \mathrm{~W} / \mathrm{m} \mathrm{K}} \\
& h 1=16,79 \mathrm{~W} / \mathrm{m} 2 \mathrm{~K}
\end{aligned}
$$

Mencari nilai $h$ cairan baterai, jika properti dianggap sama dengan air :

Diketahui dari tabel sifat air pada suhu

$$
\begin{aligned}
\mathrm{v} & =7,08 \times 10^{-7} \mathrm{~m}^{2} / \mathrm{s} \\
\beta & =1,8 \times 10^{-3} \mathrm{~K}^{-1} \\
\alpha & =1,43 \times 10^{-7} \mathrm{~m}^{2} / \mathrm{s} \\
\mathrm{k} & =0,623 \mathrm{~W} / \mathrm{m}^{0} \mathrm{~K}
\end{aligned}
$$

$$
\begin{array}{ll}
\mathrm{L} & =0,117 \mathrm{~m} \\
\mathrm{Tw} & =37,2 \mathrm{C}=310,2 \mathrm{~K} \\
\mathrm{Ts} & =37,1 \mathrm{C}=310,1 \mathrm{~K}
\end{array}
$$

Maka dengan persamaan Rayleigh dapat dicari:

$\mathrm{Ra}=\frac{10 \cdot 1,8 \times 10^{-3}(310,2-310,1) \cdot(0,117)^{3}}{7,08 \times 10^{-7}}$

$$
7,08 \times 10^{-7} .1,43 \times 10^{-7}
$$

Ra $\quad=3,59 \times 10^{7} \leq 10^{9}$

Aliran fluida adalah laminer maka nilai :

$$
\begin{array}{cl}
\mathrm{n} \quad=0,59 \\
\mathrm{C} \quad=1 / 4 \\
\quad N u=\frac{h \cdot L}{K}=\mathrm{C} . \mathrm{Ra}^{\mathrm{n}} \\
\quad N u=\frac{h \cdot L}{K}=0,59 .\left(3,59 \times 10^{7}\right)^{1 / 4} \\
N u=\frac{h \cdot L}{K}=45,6
\end{array}
$$

Maka dapat dicari nilai $\mathrm{h}$ :

$$
\begin{gathered}
45,6=\frac{h \cdot 0,117 \mathrm{~m}}{0,623 \mathrm{~W} / \mathrm{m} \mathrm{K}} \\
h 2=233,035 \mathrm{~W} / \mathrm{m} 2 \mathrm{~K}
\end{gathered}
$$

Dari perhitungan di atas, didapatkan nilai h udara dan air, maka perpindahan panas menyeluruh dapat dicari dengan persamaan :

$q / A=\frac{T A-T B}{1 / h 1+\sum R t h+1 / h 2}$

Dimana TA dan TB dari pengukurun sebagai berikut :

$$
\begin{aligned}
\mathrm{TA} & =337,3 \mathrm{~K} \\
\mathrm{~TB} & =310,1 \mathrm{~K} \\
\mathrm{~h} 1 & =16,79 \mathrm{~W} / \mathrm{m}^{2} . \mathrm{K} \\
\mathrm{h} 2 & =233,035 \mathrm{~W} / \mathrm{m}^{2} . \mathrm{K} \\
\sum \text { Rth } & =0,289 \mathrm{Km}^{2} / \mathrm{W}
\end{aligned}
$$

$$
\begin{aligned}
& q=\frac{(337,3-310,1) K}{\frac{1}{16,79 W / m 2 K}+0,289 K m 2 / W+\frac{1}{233,03 / m 2 K}} \\
& q \text { menyeluruh }=57,1 \mathrm{~W} / \mathrm{m}^{2} .
\end{aligned}
$$

\section{ANALISIS DAN PEMBAHASAN DATA}

Dari hasil pengukuran menggunakan cover lama dan cover baru, didapatkan hasil temperatur cairan baterai pada cover lama adalah $64,4{ }^{\circ} \mathrm{C}$ dan pada cover baru adalah $43,1{ }^{\circ} \mathrm{C}$ dalam 180 menit berkendaraan, didapatkan bahwa temperatur cairan baterai pada cover lama lebih tinggi dibandingkan dengan cover baru. Hal ini dikarenakan cover baru dilengkapi penambahan isolasi Polyurethane 


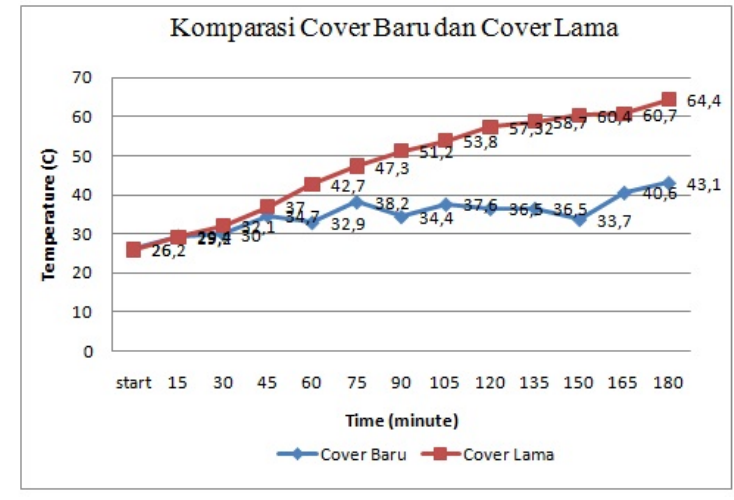

Gambar 13. Komparasi Temperatur Baterai Cover Baru dan Lama

Cover lama merupakan bahan cartonplast dengan tebal $2.5 \mathrm{~mm}$ tanpa isolasi polyurethane, karenanya, penyerapan panas menjadi lebih besar. Panas dari mesin melewati dua lapis bahan yang terdiri dari cover luar (cartonplast $\mathrm{t} 2.5 \mathrm{~mm}$ ) dan dinding baterai (PP $\mathrm{t} 5 \mathrm{~mm}$ ). Penyerapan panas yang terjadi pada cover lama ialah $66,18 \mathrm{~W} / \mathrm{m}^{2}$, dan temperatur cairan baterai adalah $64,4{ }^{\circ} \mathrm{C}$.

Sementara itu cover baru merupakan bahan cartonplast dengan tebal $2.5 \mathrm{~mm}$ dengan isolasi Polyurethane, karenanya penyerapan panas menjadi lebih kecil dibandingkan cover lama. Panas dari mesin melewati tiga lapis bahan yang terdiri dari cover luar (cartonplast $\mathrm{t} 2.5 \mathrm{~mm}$ ), isolasi Polyurethane (PU t735mm), dan dinding baterai (PP t5mm). Penyerapan panas yang terjadi pada cover baru ialah $57,1 \mathrm{~W} / \mathrm{m}^{2}$.

Penambahan isolasi pada cover baru dilakukan untuk mendapatkan nilai hambatan thermal yang lebih besar, yang akan menurunkan nilai laju perpindahan panas pada cover. Pada perhitungan, didapatkan tebal isolasi adalah 7,4 mm dan temperatur cairan baterai dipertahankan $40^{\circ} \mathrm{C}$. Namun pada cover, isolasi yang digunakan adalah dengan ketebalan $7,5 \mathrm{~mm}$ sesuai dengan yang tersedia di pasaran.

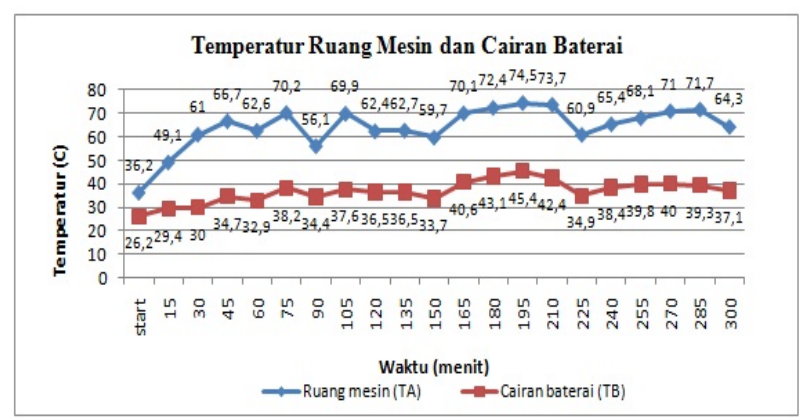

Gambar 14. Temperatur ruang dan cairan baterai

Dari grafik pengukuran temperatur ruang mesin dan cairan baterai selama 300 menit, dapat dilihat temperatur cairan baterai tertinggi ialah $45,4{ }^{\circ} \mathrm{C}$ pada menit ke 195 . Kenaikan temperatur dari target $40^{\circ} \mathrm{C}$ dipengaruhi oleh kondisi temperatur dan keadaan lingkungan. Pada kondisi tersebut, temperatur ruang mesin adalah $74,5{ }^{\circ} \mathrm{C}$ dan keadaan jalanan yang padat. Oleh karena itu, kondisi lingkungan sangat mempengaruihi perubahan temperatur cairan baterai.

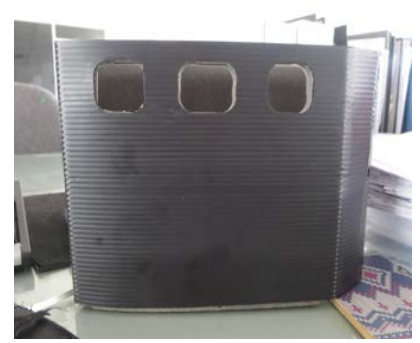

Gambar 15. Cover Baterai Baru

Pemilihan isolasi baru pada cover ialah bahan dengan nilai konduktivitas termal rendah. Konduktivitas Termal (daya hantar panas) yaitu sifat bahan yang menunjukkan seberapa cepat suatu bahan menghantarkan panas konduksi. Dalam persamaan konduksi yaitu $\mathrm{q} / \mathrm{A}=\mathrm{k} . \Delta \mathrm{T} /$ $\Delta \mathrm{X}$, nilai $\mathrm{q}$ berbanding lurus dengan nilai $\mathrm{k}$. Artinya semakin besar $\mathrm{k}$, maka semakin besar nilai q, dan sebaliknya, semakin kecil nilai $\mathrm{k}$, maka semakin kecil pula laju perpindahan panas q.

Nilai hambatan termal total $\sum$ Rth untuk cover lama ialah 0,0386 sedangkan cover baru ialah 0,289. Semakin besar hambatan termal maka semakin kecil nilai q konduksi yang dihasilkan. Pada cover lama, besarnya laju perpindahan panas konduksi adalah 101,12 W/m² sedangkan pada cover baru adalah $82,87 \mathrm{~W} / \mathrm{m}^{2}$. Penurunan besar laju perpindahan panas konduksi pada cover baru dikarenakan adanya penabahan isolasi Polyurethane, sehingga total hambatan termal pada cover baru menjadi lebih besar.

Beberapa bahan dengan nilai konduktivitas termal rendah dapat digunakan sebagai bahan cover baterai, seperti Fiberglass $\mathrm{K}: 0,04 \mathrm{~W} / \mathrm{m}{ }^{\circ} \mathrm{K}$, Wool felt $\mathrm{K}:$ 0,07 W/m ${ }^{\circ} \mathrm{K}$, Polyester $0,05 \mathrm{~W} / \mathrm{m}$ ${ }^{\circ} \mathrm{K}$ dan lainnya. Bahan tersebut dapat digunakan sesuai dengan kebutuhan produsen mobil, syarat dan standar perusahaan, serta sesuai dengan budget projek suatu unit mobil.

\section{SIMPULAN}

Dari pengukuran dan perhitungan dapat disimpulkan bahwa

1. Besarnya q konduksi pada cover lama adalah 101, $12 \mathrm{~W} / \mathrm{m}^{2}$ dan pada cover baru adalah $82,87 \mathrm{~W} / \mathrm{m}^{2}$.

2. Besarnya $\Sigma$ Rth pada cover lama adalah $0,0386 \mathrm{~K} \mathrm{~m}^{2} / \mathrm{W}$ dan pada cover baru adalah $0,2886 \mathrm{~K} \mathrm{~m}^{2} / \mathrm{W}$. 
3. Besarnya laju perpindahan panas menyeluruh pada cover lama adalah 66, $18 \mathrm{~W} / \mathrm{m}^{2}$ dan pada cover baru adalah $57,1 \mathrm{~W} / \mathrm{m}^{2}$.

4. Pemilihan isolasi Polyurethane dilakukan karena memiliki nilai konduktivitas thermal yang rendah.

5. Ketebalan isolasi Polyurethane adalah 7,5 $\mathrm{mm}$.

6. Besarnya temperatur cairan baterai pada menit ke 180 untuk cover lama adalah 64,4 ${ }^{\circ} \mathrm{C}$ sedangkan dengan penambahan tebal isolasi dan modifikasi cover baterai, temperatur cairan baterai menjadi $45,4{ }^{\circ} \mathrm{C}$.

7. Cover baru memiliki nilai $\mathrm{q}$ dan temperatur cairan baterai lebih kecil dari pada cover lama. Dan cover baru memiliki hambatan thermal total yang lebih besar dari pada cover lama.

8. Nilai q bergantung pada besarnya hambatan thermal. Semakin besar nilai hambatan, semakin kecil nilai q.

9. Nilai q menyeluruh ditentukan oleh koefisien perpindahan panas konveksi dan perubahan temperatur fluida.

\section{DAFTAR PUSTAKA}

Holpman, J.P., Heat Transfer $10^{\text {th }}$ edition, McGraw-Hill Book Company, Inc., New York, 2010.

Yunus, Asyari D., Diktat Perpindahan Panas dan Massa, Universitas Darma Persada, Jakarta, 2009.

Mitrakusuma, Windy, H., Diktat Dasar Refrigerasi- B2 Termodinamika dan Perpindahan Panas, Paper.

, JIS D5301-2006, Japanese Standards and Association, Tokyo, 2006.

, Charging Valve Regulated Lead Acid Battery, C\&D Technology, Inc, USA, 2012. , Lead Acid Battert- Technical Paper, PowerThrough, USA, 2012.

Handbook for Stationary Lead-Acid Batteries - Part 1: Basics, Design, Operation Modes and Applications, GNB Industrial Power, - , 2012.

Yoder, John A, DOE Handbook - Primer on Lead Acid Storage Batterie, Department of Energy, Washington, D.C, 1995. 